\title{
Challenges and the Results Approach Facing Sustainability in an Unequal World: The Sub-Saharan Africa Case Study
}

\author{
Chukwudi Johnson Chimezia
}

\begin{abstract}
Sustainability could be defined as an ability or capacity of something to be maintained or to sustain itself. It's about taking what we need to live now, without jeopardizing the potential for people in the future to meet their needs. However, the manner in which indigenous people of sub-Saharan Africa interact and exploit their ecology could cause massive damages to achieve sustainability in the contemporary society. Although, the developed countries face diminutive challenges on sustainability due to the legislature system and the regulation that is being practiced and implemented. This paper presents in depth the challenges facing sustainability in sub-Saharan countries and their adverse effects to the society. Also, it suggests the possible solutions on how to overcome the scourge.
\end{abstract}

Index Terms-Sustainability, ecology systems, pollution, economy.

\section{INTRODUCTION}

Sustainability is wide approaches individuals are talking about in an epoch when ecological crisis is caused as results of human activities that are requiring immediate solutions. Brundtland [1] defined "sustainable development; as development that meets the needs of the present without compromising the ability of future generations to meet their own needs". Brundtland's [1] definition is clearly linked to the term "sustainability" which has the components such as, ecology, social and economic. Nonetheless, human activities play a disastrous role in order to achieve sustainability. This paper focuses on the challenges facing sustainability such as; deforestation, erosion, pollution, economic, environmental and natural resources in Africa.

Although some miniature indigenous people in various communities in sub-Saharan states argued that, if their governments could cultivate and implement the edict of developed countries, there is a possibility to achieve sustainability, in addition, their countries could be in the same trajectory with the developed countries. However, the road to this scourge becomes threat to their governments and the people itself due to the counterproductive that faces sustainability such as; political incorrectness, economic mismanagement, wealth misconduct, conflict, inequality and inequity, poverty, genocide, hurricane, corrupt civil servants, natural disasters, not enough jobs or houses, high temperatures, population pressure, lack of technology and

Manuscript received October 3, 2014; revised May 13, 2015.

Chimezia Chukwudi Johnson is with the Department of Social Work, University of South Africa, Pretoria, South Africa (e-mail: armstrongsmart@yahoo.co.za). machinery.

\section{SuStAINABILITY}

The broad concept of sustainability is based on the assertion that people and their communities comprises of social, economic, and environmental systems that are in steady interaction and that must be kept in harmony or balance if the society is to continue to function to the benefit of its indigenous people now and in the future. A healthy, balance nation or community is one that can endure into the future, providing a decent way of life for all its inhabitants [2], it is a sustainable society. Sustainability is an ideal of toward which to strive and against which to weigh proposed actions, plans, expenditures, and decisions [3]. It is a way of looking at a community or a society or a planet in the broadest context, in both time and space [2]. However, it adopts a broad perspective from various fields of study or disciplines. In practice the pursuit of sustainability fundamentally endeavor because every community has different social, economic, environmental needs and concerns.

\section{THE RECIPE TO ACCOMPLISH SUSTAINABILITY IN THE COMMUNITY OR NATION AMONGST ITS INHABITANTS}

Based on the assertion given above we can draw upon in general that for any society to achieve sustainability, the following principles of sustainability can help a community ensure its social, economic, environmental systems are well integrated and endure. We should remember that, although the list of principles is helpful, however, each of them has the potential to overlap and inter-relate with some all of the others. A community or nation that wants to pursue sustainability will try to:

Maintain and, if possible, enhance, its inhabitants quality of life. Although quality of life differ from community to community. It has many factors: income, education, health care, employment, housing, legal rights on the one hand; pollution, disease, exposure to crime, disaster, and other risks on the other. One city may be proud of its secure streets, high quality schools, and rural atmosphere, while another thinks that employment opportunities and its historical heritage is what makes it an attractive place to reside. Each locality must define and plan for the quality of life it wants and believes it can accomplish, for now and for future generations.

Enhance local economic vitality. A feasible local economy is crucial to sustainability. This comprises job opportunities, sufficient tax base and revenue to support government and the 
provision of infrastructure and services, and a suitable business climate [2]. A sustainable economy is also diversified, so that it is not easily disrupted by internal or external events or disasters, and such an economy does not simply shift the costs of maintaining its good health onto other regions or onto the oceans or atmosphere. Nor is a sustainable local economy reliant on unlimited population growth, high consumption, or non-renewable resources [4].

Promote social and intergenerational equity. A sustainable community's resources and opportunities are available to everyone, regardless of their traditions, age, gender, cultural background, religion, or other characteristics [5]. Further, a sustainable community does not deplete its resources, destroy natural systems, or pass along unnecessary hazards to its great-great-grandchildren.

Maintain and enhance the quality of the environment. A sustainable community or nation perceives itself as existing within a physical environment and natural ecosystem and tries to find ways to co-exist with that environment. It does its part by avoiding unnecessary degradation of the air, oceans, fresh water, and other natural systems. It tries to replace detrimental practices with those that allow ecosystems to continuously renew themselves. In some cases, this means simply protecting what is already there by finding ways to redirect human activities and development into less sensitive areas. But a community may need to take action to reclaim, restore, or rehabilitate an already-damaged ecosystem such as a nearby wetland.

Incorporate disaster resilience and mitigation into its decisions and deeds. A community is resilient in the face of inevitable natural disasters like tornadoes, hurricanes, earthquakes, floods, and drought if it takes steps to ensure that such events cause as little damage as possible, that productivity is only minimally interrupted, and that quality of life remains at (or quickly returns to) high levels. A disaster-resilient community further takes responsibility for the risks it faces and, to the extent possible, is self-reliant. That is, it does not anticipate that outside entities (such as federal or state government) can or will mitigate its hazards or pay for its disasters [6].

Use consensus-building, participatory process when making a decision. Participatory processes are essential to community sustainability. Such a procedure engages all the people who have a stake in the outcome of the decision being contemplated. It encourages the identification of concerns and issues, promotes the wide generation of ideas for dealing with those concerns, and helps those involved find a way to reach agreement about solutions. It results in the production and dissemination of important, relevant information, fosters a sense of community, produces ideas that may not have been considered otherwise, and engenders a sense of ownership on the part of the community for the final decision [2].

\section{DEFORESTATION}

Deforestation is the process whereby natural forests are cleared through logging and/or burning, either to use the timber or to replace the area for alternative uses [4]. Population pressure in Africa leads to deforestation on a massive scale. Although the major causes of deforestation in Africa are chopping down of indigenous plant life, climate change, demand for fire wood as a means to supply their energy daily needs. Cornwell and De Beer [7] account that, 1, 3 billion people throughout the world are chopping down firewood faster than new trees can be planted or old ones replaced by natural regrowth. For example in Nigeria, Burkina Faso and Tanzanian over 90 per cent of the total national energy consumption consists of wood. In addition, in rural areas people gather wood freely for their personal use, or they process it and sell it in the cities as charcoal. Cornwell and De Beer [7] state that five to six tons of wood are needed to produce one ton of charcoal, but there are advantages using charcoal.

Firewood is used at a tremendous rate in Africans and any shortage affects the lives of its inhabitants in a very real way. For examples, in some parts of West Africa households traditionally cooked two meals a day. Now that wood has become scarce, families can often cook only one meal every second day. Another example comes from Burkina Faso, where soya beans were introduced because they are a highly nutritious source of vegetable protein. The beans grow extremely well, but few people use because they take so long to cook and firewood is in short supply according to Cornwell and De Beer [7]. Throughout Africa, the spread of disease is aggravated by the evidence that there is not enough wood to heat food or boil water properly. And households are unable to do much about raising their standard of living since so much time is spent collecting firewood.

Trees are not chopped down purely for energy needs and private consumption as timber export is a major source of foreign exchange for African countries and provide many job opportunities [8]. The rate at which trees are demolished for this purpose and the resultant dwindling of the forests of Africa are causing grave concern. In 1980 Liberia earned \$84 million-11 per cent of its export revenue-from timber. In order to earn this revenue, some 80000 hectares of the country's forests are chopped annually.

\section{EFFECTS OF DEFORESTATION}

Forests are complex ecosystems that are important to the carbon and water cycles that sustain life on earth. When they are degraded, it can set off a devastating chain of events both locally and around the world [9].

Loss of species: It is estimated that seventy percent of world's plants and animals live in forests and are losing their habitats to deforestation. Loss of habitat can lead to species extinction. This is not only a biodiversity tragedy but also has negative consequences for medicinal research and local populations who depend on the animals and plants in the forests for hunting and medicine.

Carbon emissions: Healthy forests help absorb greenhouse gasses and carbon emissions that are caused by human civilization and contribute to global climate change. Without trees, more carbon and greenhouse gasses enter the atmosphere. To make matters worse, trees actually become carbon sources when they are cut, burned, or otherwise removed. 
Soil erosion: Without tree roots to anchor the soil and with increased exposure to sun, the soil can dry out, leading to problems like increased flooding and inability to farm. The scientists estimate that a third of the world's arable land has been lost to deforestation since 1960 [9]. Cash crops planted after clear cutting or burning — like soy, coffee, and palm oil - can actually exacerbate soil erosion because their roots cannot hold onto the soil the way trees' can.

Life quantity: Soil erosion can also lead to silt entering the lakes, streams, and other water sources. This can decrease local water quality, contributing to poor health in the local population.

All of these factors can have adverse effects on local economies. Increased flooding, lack of quality water, and inability to produce their own food causes many locals migrate to cities that lack infrastructure for them [9]. Or, they work on plantations, worsening the deforestation problem and at times being subjected to inhumane working conditions.

\section{POSSIBLE SOLUTIONS}

Trees planting: An attempt should be made to alert Africa's people to importance of tree planting. Trees give off oxygen that is essential for human existence and they, in turn, capture carbon dioxide that humans and animals exhale. Trees also help in containing water in its root. With this simple act, you are able to prevent soil erosion, which is the root cause of landslides [10].

Renewable energy: Africa's people should be in a position to rely on renewable energy such as sun and wind rather than firewood. But there are technological and economic problems that make it impossible to replace conventional energy with these alternatives. According to Cornwell and De Beer [7] state that energy from renewable sources may appear free, but the technology involved in using them is not.

More land for afforestation: One country in which afforestation has been an enormous success is Kenya. The Kenya Wood fuel project, initiated in the late 1970s, still operating effectively and getting support from government, international funders and the local population.

Effective use of wood-burning stoves to reduce per capital wood consumption. However, these and other forest conservation measure can only succeed if they are tested locally and adapted to prevailing conditions. It would moreover require a large staff of trained people and sufficient economic and institutional incentives to persuade people to plant trees and try out new technology.

\section{EROSION}

Erosion refers to the process of being eroded by water, wind or other natural agents. It may also refer to a condition in which earth's surface is worn away, or destruction of tissue or tooth enamel by physical or chemical action. The various forms of erosion are: water, wind, surface, fluvial, sheet, gully, rill, tunnel gullying, and mass-movement. In brief we shall only discuss water and wind erosion below.

Water erosion: "wherever there is rainfall there is possibility of water erosion and wherever water runs off over the surface of the soil there is sure to be erosion. The amount of soil washing, or soil losses, depends upon the total amount as well as the intensity of individual rains, the length and steepness of the slope, the type of the soil, the kind and density of the crops covering the soil and the method of cultivating the soil" according to Kircher and McNall [11].

Wind erosion: this kind of erosion takes place where the soil is dry and little or no vegetative cover is maintained on the field. Kircher and McNall [11] maintain that some land that is too closely pastured, or that has been burned over, is subject to wind erosion.

There are various causes of erosion which could serve has stumbling blocks in other to achieve sustainability such as land use, climate, soil, hydrology, landforms, removal of plant cover, consequences on livelihood, flooding and contribution to poverty.

Land use: Humans play a major role in soil erosion through their use and abuse of natural resources, for example deforestation, grazing, arable land use, faulty farming systems, high crop intensity, housing construction and mining [12].

Climate: The two most important climatic factors having a direct effect on erosion are precipitation and wind velocity. Other climatic factors have an indirect effect on soil erosion, such as water balance, evapotranspiration, temperature and relative humidity. Indirect factors affect the erosivity of rainfall by altering the soil moisture regime and the proportion of rainfall that may become surface runoff. For erosion control it is necessary to investigate physical characteristics of rainfall, including the amount, distribution, intensity, energy load, seasonality and variability of rainfall and the formation and course of surface runoff.

Soil: The susceptibility of a soil to erosion is influenced by its physical, hydrological, chemical and mineralogical properties as well as its soil profile characteristics [13], [14]. Important soil physical and hydrological properties that affect the resistance of a soil to erosion include texture, structure, and water retention and transmission properties [14].

Hydrology: Infiltration, surface detention, overland flow velocity, and subsurface water flow are important soil erosion components of the hydrological cycle. The different types of flow and their velocities may be turbulent or laminar, steady or unsteady, uniform or non-uniform and influence the extent of erosion [13].

Landforms: Slope gradient, slope length and shape of slope are the important variables of landform that affect erosion processes for all types of soil erosion, e.g. splash, sheet, rill, and gully erosion [13], [14].

In many parts of Africa the soil is very poor in nutrients. Cornwell and De Beer [7] points out that, although the vegetation grows very densely, particularly in the tropics, this is not really due to soil fertility. The major reason is high temperatures that cause vegetable matter to decompose rapidly, which creates an extremely fertile but thin layer on the soil surface. Deforestation, collection of firewood, cultivation of the soil for farming purposes and the destruction of trees to eradicate tsetse fly all help to remove vegetation and consequently the nutrients disappear. Example is a village in eastern region in Nigeria where collection of firewood for food processing, energy supply and demolition 
of trees for means of livelihood; as a results what remains is a thin layer of arable soil which is soon washed away by rain or exhausted by over cultivation.

In addition, Africa's rainfall pattern also contributes greatly to soil erosion. The reason why rain is the principle cause of soil erosion is that raindrops hit the earth at 50 kilometers per hour. During the heavy storms experienced in many parts of Africa, $25 \mathrm{~mm}$ of rain falling within one hour can release enough energy to plough the soil to a depth of 250 mm. Harrison [15] cites the example of northern Nigeria where 90 per cent of the rain pours down at a rate of $25 \mathrm{~mm}$ per hour. Cloudburst in Ghana cause falls of up to $200 \mathrm{~mm}$ per hour. Sudden storms are harmful to sustainability of any community or nation since most of the water is lost and in the process washes away large quantity of valuable topsoil.

\section{POSSIBLE SOLUTIONS}

The following factors could help to prevent erosion and soil degradation if applied for: The government of sub-Saharan countries should concentrate on effectively use of fertilizer, provide full support financially and academically for agricultural engineers, and then alert its inhabitants how vital the environment it is.

If we are to prevent erosion of bare soil, it is important to maintain a vegetation cover, especially in the most vulnerable areas e.g. those with steep slopes, a dry season or periods of very heavy rainfall [16]. To do this may mean only partially harvesting forests (e.g. alternate trees) and using seasonally dry or wet areas for pastoral rather than arable agriculture.

Where intensive cultivation takes place, farmers should use a crop rotation in order to prevent the soil becoming exhausted. Where soils are ploughed in vulnerable areas, contour ploughing (i.e. round the hillside rather than down the hillside) should be used. Careful management of irrigation, to prevent the application of too much or too little water, should help reduce the problem of salination [16].

Perhaps an attempt should be made to restrict highway construction and urbanization to areas of lower agricultural potential. With extractive industries, a pledge must be secured to restore the land to its former condition before planning permission for quarries or mines is granted.

\section{POLLUTION}

The term pollution refers to the act of contaminating ones environment by introducing certain hazardous contaminants that disturb the ecosystem and directly or indirectly affect the living organisms of that ecosystem. Pollution in general is the activity of disturbing the natural system and balance of an environment. The increase in the pollution over the years by man has caused severe damage to the earth's ecosystem. It is responsible for global warming which is leading to the end if all the lives on earth [17]. Over the years there is an extreme increase in the rate of human diseases, and death rate of various animals and plants on earth, and that is all because of the pollution caused by man himself. Although there are various forms of pollution, but five of them have the most perilous effect on our lives. Following are the five most dangerous types of pollution and their causes:

Water pollution: It is estimated that $75 \%$ of the earth surface is covered with water and more than half of the total population earth's species lives in water. In addition all inhabitants of this world life greatly depend on water for survival and without water life is impossible. Water pollution not only affects the fish and animals living in the water but also affects the whole food chain by also transferring the contaminants to the consumers depending on these animals. Water used from a polluted lake directly contaminates its user. Many of the water creatures are on the verge of extinction due to the dramatic increase in the water pollution. Water pollution is caused by the direct incorporation hazardous pollutants. The sources of these pollutants are yet again the large industries and factories that dispose of their waste in lakes and ponds.

Air pollution: Are precisely the most common and the most dangerous types of pollution. It involves the direct release of chemicals into the environment. The chemicals then become the part of the air around us that all the living things take in. The increase in the rate of diseases such as asthma and lung cancer today is due to the increase in the air pollution around us. Air pollution is also a cause of global warming and acid rain.

The causes of air pollution: basically the air pollution is caused by the burning of fuel that directly releases hazardous chemicals into the air. For example the burning of coal releases sulfur dioxide, a poisonous gas which is responsible for acid rain. The sources of such chemicals are the large factories, smoke from the vehicles, chimneys and burning of wood.

Soil pollution: Soil pollution involves the contamination of soil by the release of harmful substances into the soil. Unlike air pollution, which has a direct effect on human lives, soil pollution causes an indirect damage to humans and other animals. The lives of all the living things depend on three sources: water, light and soil. The plants which are the producers of the food chain take up their nutrients, which are essential for their living, from the soil [18]. The nutrients taken by the plants are then transferred to the consumers that depend on these plants. Hence a soil consisting of contaminants will not only affect the plants growing on the soil but it will also indirectly harm the entire food chain.

Causes of soil pollution: Soil pollution is mainly caused by the release of industrial waste. This waste is directly incorporated into the soil by large industries and factories. Soil pollution is also caused by human acts as mining and deforestation.

Noise pollution: Unlike other the above mentioned types of pollution do not involve hazardous chemicals or their incorporation into the environment, rather noise pollution is the increase in the rate of noise in the environment. Noise is defined as an unpleasant sound that has an adverse effect on the human ear. Noise can be extremely dangerous. And it is all around us. It penetrates into human mind and controls it. Too much noise leads to severe psychological illness and badly affects the behavior. It leads to hypertension, stress, aggression and annoyance. Moreover, it causes depression and forgetfulness. 
Causes of noise pollution: Noise pollution are caused by the moving vehicles, manmade machines and loud music. Other than that noise can be caused by anything, but these three sources are the main reasons for the noise pollution around us [17].

Land pollution: Land pollution is the degradation of the Earth's surface caused by a misuse of resources and improper disposal of waste.

Some examples of land pollution include:

- Litter found on the side of the road

- Illegal dumping in natural habitats

- Oil spills that happen inland

- The use of pesticides and other farming chemicals

- Damage and debris caused from unsustainable mining and logging practices

- Radiation spills or nuclear accidents

Land pollution is responsible for damage done to natural habitat of animals, deforestation and damage done to natural resources, and the general uglying up of our communities [19].

These kinds of pollution are commonly found in Africa's countries where the misuse of pesticides kills the natural predators of insects as well as the insects that pollinate crops; in addition it encourages the evolution of insects that are resistant to the pesticide.

\section{Possible Solutions}

Pollution affects all the elements of an ecosystem, including air, water and soil. Solutions must be found to combat all types of pollution so that delicate ecosystems can thrive once again.

"Since these and other forms of pollution tend to be localized, they can be controlled provided sufficient funds are channeled into appropriate machinery and technology. Remedies to pollution require consideration capital and scientific and administrative expertise and theses are often in short supply in developing countries" according to Cornwell $\&$ De Beer [7].

To help prevent top soil pollution, follow the same steps used to prevent water pollution, such as changing over to organic cleaners and detergents, and disposing of toxic chemicals and solvents responsibly.

Clean energy-clean energy is renewable energy which does not deplete natural resources or cause environmental harm. Renewable energy includes bioenergy, wind, hydroelectricity, solar and geothermal energy [20].

\section{NAtural Resources}

Natural resources are anything that exists naturally in any environment, undistributed by man, in their natural form [21]. They are considered valuable and useful to man in their natural form, depending on their quantity and demand. They include: the land, forests, energy sources and minerals. Africa produces a large proportion of the world's supply of several minerals that are economically and strategically important. For some decades now, developed countries depended on
Africa to supplement its mineral supplies. The mining of economically viable minerals is of tremendous important for African sustenance. Many parts of the Africa's states have valuable resources, For instance Southern Africa (gold, diamonds, platinum, uranium, coal, iron, ore, phosphates, manganese, chrome and copper) [22] North Africa (phosphates), West Africa (oil, iron ore, phosphates and bauxite) and Central Africa (copper, iron ore, uranium, oil and diamonds). Countries such as South Africa, Zimbabwe, Zambia, Democratic Republic of Congo, Libya, Algeria, Nigeria and Gabon rely mainly on minerals for their wealth.

Despite the vast minerals resources that can be economically extracted from many parts of the continent they still consumes remarkably little conventional energy resources. With the exception of South Africa, African population, constituting over 10 per cent of the world population, accounts for a mere 2 per cent of the world conventional energy. According to Timberlake (as cited in [7]) says that, South Africa alone accounts for 25 per cent of Africa's total energy consumption.

Furthermore, with minor exceptions, Africa does not consume or add significant value to these and other mineral products which it has in abundance. Rather, we are net exporters of raw materials that fuel prosperity and development in other regions. Africa is largely seen as a price taker rather than a price-maker, with a marginal role in international trade [23], [24].

In recent years, the depletion of natural resources has become a major focus of governments and organizations [5], [21]. Depletion of natural resources is associated with social inequity. Considering most biodiversity are located in developing countries, depletion of this resource could result in losses of ecosystem services for these countries. Some view this depletion as a major source of social unrest and conflicts in developing nations. The depletion of natural resources is mainly caused by demography, economy, society, politics, mining, petroleum extraction, conflict, social unrest and technology.

In order to stabilize the overexploitation and depletion of natural resource the following recipes should be consider and implemented:

Important structural measure is a better integration of Africa's development policies [5]. Africa needs to embed long term development objectives firmly into the processes for extracting natural resources. For mining to benefit Africa's people, strong backward and forward linkages in the local economy should allow local entrepreneurs and industrialists to take advantage of service provision and technology transfer opportunities as a result of proximity to the mining industry. This means investment in infrastructure, research and human capital development, through conditionality for local content. This is what other regions have done; this is what Africa needs to do.

Other factors such as the building of human and institutional capacities towards a knowledge economy that supports innovation, research and development and the promotion of good governance of the mineral sector in which communities and citizens participate in decision making and in mineral assets, and in which there is equity in the distribution of benefits are also necessary pre requisites. 


\section{CONCLUSION}

Sustainability is a process which could be elongate to achieve in sub-Saharan Africa countries due to the manner in which its inhabitants approaches their ecology, marginalization between the "haves" and the "have- nots", and severity of poverty that is forcing them to overexploit the natural resources. Also, the developed world is an equally large threat because its approach to development is based on large-scale industrialization. Although South Africa is still the country so far in Africa that is in process of achieving sustainability and could be on the same trajectory with the developed countries. Therefore, the road to sustainability is a long way in Africa; however, the future is still bright for Africa's countries and its inhabitants, if the facts above are cultivate, embrace, being practice and put into action.

\section{REFERENCES}

[1] C. Regan, 80:20 Development in an Unequal World, Educating and Acting for a Better World, Ireland: Bray, 2006.

[2] J. Monday, Building Back Better, Boulder, Colo.: University of Boulder, Natural Hazards Research and Applications Information Center, 2002.

[3] J. Whitman, The Sustainability Challenge for Southern Africa, London: Macmillan, 2000.

[4] The Corporation of the City of SarniaIntegrated Community Sustainability Plan. (March 2013). City of Sarnia, Integrated Community Sustainability Plan. [Online]. Available: http://www.city.sarnia.on.ca/documents.asp?DocumentID=226

[5] WWF Global. (2009). Deforestation. [Online]. Available: http://wwf.panda.org/about_our_earth/about_forests/deforestation.

[6] S. C. Hackett, Environmental and Natural Resources Economics: Theory, Policy, and the Sustainable Society, New York: Armonk, 2011.

[7] A. Anthony, Ecological crisis in Africa as a Challenge to Lasting Cultural and Sustainable Development: A Theological Approach, Frankfurt: Peter Lang, 2011.

[8] L. Cornwell and F. de Beer, Only Study Guide for DVA1501, Pretoria: University of South Africa, 2010.

[9] F. Nelson, Community Rights, Conservation and Contested Land: The Politics of Natural Resource Governance in Africa, London: Routledge, 2012.

[10] J. Szalay. (2013). Deforestation: facts, causes and effects. [Online]. Available: http://www.livescience.com/27692-deforestation.html

[11] N. Fiset. (2007). 8 ways of preventing deforestation. [Online]. Available: http://ezinearticles.com > Insurance > Health

[12] P. McNall and H. Kircher, Our Natural Resources, Danville, Ill.: Interstate Printers and Publishers, 1970.

[13] Central Board of Secondary Education. (2013). Geography land forms teachers' manual. [Online]. Available: http://www.cbse-international.com/cbse...4/l-4_c-45_1350898056287 .pdf

[14] Civcal. (2001). Causes of soil erosion. [Online]. Available: http://civcal.media.hku.hk/soilerosion/causes/default.htm

[15] P. Gupta and S. Uniyal, "A case study of ramgad watershed, nainital for soil erosion risk assessment using corine methodology," International Journal of Engineering Research and Technology, vol. 1, no. 10, ESRSA Publications, 2012.

[16] D. Thad and L. Harrison. "Cross-cutting cleavages and ethnic voting: An experimental study of cousinage in Mali," American Political Science Review, vol. 104, no. 1, pp. 21-39, 2010.

[17] M. Jain and D. Das, "Estimation of sediment yield and areas of soil erosion and deposition for watershed prioritization using gis and remote sensing," Water Resources Management, vol. 24, no. 10, pp. 2091-2112, 2009.

[18] Hassam. (2011). Types and causes of pollution. [Online]. Available: http://hassam.hubpages.com > ... > Environment and Green Issues > Pollution

[19] G. Mark, The Feeding of Nations: Redefining Food Security for the 21st Century, Boca Raton: CRC Press, 2012.

[20] S. S. Ashraf. (2013). Raising environmental awareness through applied biochemistry laboratory experiments. Biochemistry and Molecular Biology Education. [Online]. 41(5). pp. 341-347. Available: http://onlinelibrary.wiley.com/doi/10.1002/bmb.20717/abstract

[21] A. Gasparatos and P. Stromberg, Socioeconomic and Environmental Impacts of Biofuels: Evidence from Developing Nations, New York: Cambridge University Press, 2012.

[22] H. B. Kircher and P. E. McNall, Our Natural Resources, Danville, 1976.

[23] J. Runge and J. Shikwati, Geological Resources and Good Governance in Sub-Saharan Africa: Holistic Approaches to Transparency and Sustainable Development in the Extractive Sector, Boca Raton: CRC Press, 2011.

[24] F. Parry. (2013). The politics of natural resources trade and industrial policy in Africa. [Online]. Available: http://www.ilo.org/wcmsp5/groups/public/---ed_dialogue/---actrav/do cuments/meetingdocument/wcms_235937.pdf

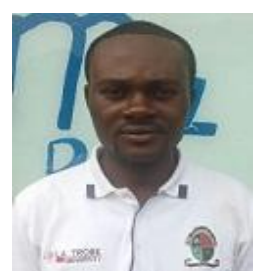

Chimezia Chukwudi Johnson was born in Ibadan city, Oyo State, Nigeria. He received Home Health Care Certificate from Intec College, Cape Town, South Africa in 2014. He is presently pursuing a career in the bachelor of social work in development studies at University of South Africa (UNISA), Pretoria, South Africa. Based on his vast academic competency during the course of his studies, he has written two papers which were accepted in international conferences. He is a student member of South Africa Council for Social Service Profession (SACSSP). His research interest is in the field of sustainable development, development theories, issues and problems, social development, vulnerable, marginalized groups (foreigners, asylum seekers, migrants, children working and living on the streets). 